\title{
Global Governance and Turkey's Position in the Post-Global Crisis Period
}

\author{
*Zehra Vildan SERIN, Beyza Oktay \\ Fatih University, Istanbul, Turkey \\ *vserin@fatih.edu.tr
}

\begin{abstract}
Following the most recent global crisis, the necessity for a new structuring in which developing countries more actively participate in the processes of global governance has become a current issue. The aim of this paper is to offer answers to the question that how should be a governance model in which China, Turkey, Brazil, India and other G-20 countries are more active decision-makers, instead of an international monetary system dominated by the USA. Firstly, the cause of the crisis, that is, the fact that USD relatively ceased to be the reserve money will be analyzed. Secondly, the process of transformation in the IMF administration in a way to allow G-20 countries a more active participation will be addressed. Finally, Turkey's role in the restructuration of the global financial system -a process which had stemmed from the emergence of global governance through the integration of capital markets and excessive deregulation- will be analyzed, and policy recommendations for better global governance will be discussed.
\end{abstract}

\section{Keywords: International reserve, Global Financial Crisis, G-20, Turkey, gold}

\section{Introduction}

The 2008 Global financial crisis started the discussions about the U.S. dollar's functions as the world's leading currency. The U.S. dollar dominated in global finance for the most of the twentieth century. Although America's central bank, The Federal Reserve, has injecting massive amount of dollar into the global financial system but also the level of US. government debt relative to gross domestic product is at its highest point since World war II. Moreover US government has highest current account deficit and budget deficits. The U.S. is still trying the position in the world as an effective policymaking. The creation of the euro is thought a major challenge to the dollar but that changed has faded. Now the Chinese renminbi is seen as a rising competitor (Prasad, 2014). In this article, we are going to analyze the aforementioned issue about the new international monetary system starting with the general frame of 2008 financial crisis. Then, the relative loss of US dollar's reserve money characteristics and the decline of United States' hegemonic power will be emphasized. Since it is a matter of debate, returning to a new structured gold standard will be discussed with the advantages and disadvantages. While the gold standard is going to be analyzed, an empirical study on the factors influencing gold reserve levels of G-20 countries will be run in order to see which variables affect the reserve levels and to check whether the tendency is different for the G-8 and other G-20 countries. Since it is seen as a common tendency to hold more of gold reserves as buffer stock during the crisis times and also since gold has become a very important factor in global economy with its increasing value, this analysis is very crucial with its participation in the ongoing debate. Finally, Turkey's role on the reconstruction of global governance will be discussed together with other G.20

\section{Literature Review}

US have managed to create and sustain a hegemonic position in the global monetary order after the World War II. According to Venhaus US hegemonic power based on three central pillars: 1) institutional power (control over outcomes in the International Monetary Fund), 2) structural power (dollar/WallStreet dominance, forming an 'exorbitant privilege') band, 3) ideational power (Neoliberalism as the leading politico-economic ideology -especially since the 1970s). Today the system is giving change signals from unipolar which was dominated by US dollar and accompanied by other currencies pegged to the dollar as it is set in Bretton Woods system, to multipolarity (Aizenman \& NBER, 2007). The United States' panic environment following the financial crisis was the years after a very long term of current account deficits (Posen, 2008). There are many critics about dollar and its monopoly power after the financial crisis occurred in the United States and has spread all over the world. It has damaged the US reputation and confidence. The fact is seen as the US has misused its reputation as the world leading economy and currency. External debts have been built up and the US had no problem with this situation thanks to its 
recklessness. But the rest of the world did not want to continue with dollar to finance international trade and capital movements and they did not want to rely solely on US dollar no more (Tremblay, 2009). There are some facts and numbers about the US dollar dominance. The trade of other currencies for US dollars captures $85 \%$ of foreign exchange transactions. Also the price of oil is set in dollars. It is being used as currency of all international debt securities. Finally it is mentioned that more than $60 \%$ of the foreign reserves are in dollars(Eichengreen \& Gupta, 2011). Additionally there is a study showing the dollar's position as leading currency. According to this study the dollar's percentage share in total world money supply declines from $90 \%$ in 1950 s to $15 \%$ nowadays. It is also mentioned that other currencies such as the Yuan, the yen or the Euro have greater share of total world money supply (Cox, 2013). As the matter of content, in the Figure1, it can be obtained that the US dollar's share in official global foreign-exchange reserves is declining.

Canadian and Australian bond markets are too small. Brazilian and Indians are not worried about it but India preserves capital control and this strict mechanism is preventing foreign investors to reach Indian markets; Brazil increased the tax on purchase of securities for the foreigners. China also has capital controls. These are all limits to be reserve currency (Eichengreen, 2011). The closest substitute is Euro. It is being used by strong European economies. Also it is convertible and supported by money and capital markets. But Euro zone and European banks are facing an ongoing financial problems and is not trustful enough (Tremblay, 2009). This prevents Euro to meet criteria of being safe haven. The other substitute is Chinese renminbi. In reality, renminbi is not seen as a close rival for dollar because of China's status as a country. China is described by Tremblay (2009) as "totalitarian, authoritarian and repressive state regime that does not recognize basic human rights, such as freedom of expression and freedom of religion, and which crushes its linguistic and religious "minority nationalities". It is a country that imposes the death penalty, even for economic or political crimes." Since it is not easy for China to change these features in near future, it has no chance to lead the world economy with its currency (Tremblay, 2009). Also the problem with Yuan (even the most important one) is liquidity and convertibility. Furthermore it is not much trustable because of its most important industries are state-owned (Delfeld, 2012).

Cox (2013) makes a point clear by referencing Dick Bove, vice president of equity research at Rafferty Capital Markets, that if the dollar would lost its role to be the most reliable currency in the future, the US would not have right to print money to pay its debts. Rather it would be forced to pay. The existence of other profitable investment opportunities is also reminded if the currency options might be varied in the future. After the financial crisis, it was not over but continued with the second wave for quantitative easing. These actions downgraded the dollar in foreign exchange markets. Also the Europe which has been affected by the crisis that spread all over the world had deep financial problems. Since the Europe's position has got much worse, it is seen to be the case that Euro will be weaker than before and dollar will be stronger (Eichengreen, 2011).

\section{Inefficient Efforts of G-7 Countries vs. Increased Significance of the G-20 Countries}

Our starting point was the Robert Zoellick's suggestion of a new monetary system which will be developed by the active participation of developing countries' currencies. His words about the return to a gold system were also an inspiring idea also for us. That's why; our study and suggestions will heavily be on the gold reserves and gold gathering by some countries. Our thesis is that some countries trying to hold more of gold and gold will have a very important role in the future. Those people are the ones who can see it now and benefit from their actions in the future. That's why; decreasing power of US and US dollar has been focused on in this section. In the forthcoming sections, more focus will be on the new international monetary system and gold reserve situations. Globalization process is being criticized heavily. There are some parts who argue that it should be rejected and some others, on the contrary, say that it is needed for sustainable growth. It is said that "no country has ever developed successfully without participating actively in the global economy" (Bergsten, 2004). A correlation between growth and globalization is also statistically approved by several of studies. Moreover, there was no study showing a connection between openness and slow growth till 2004. Countries such as China, India, Mexico and the US are the success stories in this concern. On the other hand, Africa and Brazil were two failure examples of globalization. Inside G-7, Japan and Germany has been seen as growth laggards while Japan's globalization ratio was declining and Germany's growth ratio was flat. Middle East was also one of the bad examples of globalization to the contrary of its quick repairmen in the first post-war decades and the rise in the oil prices. It is mostly an outcome of their lagging performance because some of the most crucial development successes have seen in the countries used globalization such as Mexico, China and Egypt (Bergsten, 2004). 
Globalization is a necessary condition for sustainable growth but it is not enough since it has also costs and losers. So called Washington Consensus plays an important role in this part. Still it is seen that the original Consensus was not successful to produce growth since there were some crisis and the vulnerability of countries were affecting the reform process. It is suggested that the G-20 should take an active role for the globalization process. By doing so, their effort would be crowned if they decide to seek a leader position in the governance of new world economic order. The regulation-free nature of the global financial system, excessive deregulations and asymmetric knowledge conduced towards financial markets' high-risk and myopic behaviors. Inadequate institutional communication created disorganization in the operation of capital markets. Besides, low growth rates increased instabilities that cause inflation (Stiglitz, 2009). As Stiglitz suggests (2010); Bernanke and Greenspan doctrines have proved inadequate. Financial markets acted incorrectly in controlling risks and directing the capital to low-cost activities. Especially those countries that have independent central banks were more unsuccessful than those with dependent ones. The reason of this is the fact that countries with autonomous central banks focused solely on the target of combating inflation and threw targets such as growth, employment and financial stability out of focus. However, the effects of the crisis were bigger than the damages of inflation. In this period, G-7 countries began to fail to overcome the ambiguities that emerged in the international monetary system, because while developed countries were incurring current account deficits due to global imbalances, developing countries began to have current account surpluses and to increase their dollar reserves.

Since G-7 mostly failed to make contribution to global stability and growth and G-20 may have a chance to replace G-7 in that matter. What was wrong with G-7 was mentioned as (Bergsten, 2004):

"First, the G-7's effort to manage a constructive adjustment of the global imbalances centered on the US current account deficit without putting excessive pressure on other individual components of the world economy (notably Europe) has achieved limited success, at least to date, in large part because the G-7 excludes countries whose participation in the necessary adjustment of exchange rates is essential... Second, it is also difficult for the G-7 to function as an impartial and thus effective arbiter in major debt cases. The creditor countries have traditionally been able to impose their views on the debtor countries, including through their voting control of the international financial institutions."

Also when we look at the G-7 countries share of world output, trade, monetary reserves etc., we can see a clear decline year by year. G-7 countries are not able to manage the world economy in a very effective way. Still it can be an option for them not to withdraw completely but instead it can be a council for the rich countries.

G-20's Total Reserves: Following the Asian financial crisis in 1997, the G-20 was formed in 1999.As a result, G-20 countries started to be included in the process more actively. G-20 countries, which constitute nearly $85 \%$ of the global economic magnitude, play important roles in making institutional reforms in the global system and developing new approaches. The EU has the largest share $(26 \%)$ of the economic magnitude created globally; which is followed by the USA (23\%), China and Japan (9\%), and Germany (5\%). In this ranking, the shares of the EU and the USA are notably high. For this reason, any kind of speculative news coming from these geographies has the capacity to positively or negatively influence the markets. G-20 countries dwell on institutional reforms not only to attain demand equilibrium but also to stimulate growth. Whereas China will need to provide more social services as it shifted its focus from export industries to new local businesses, the USA will have to deal with structural expenditures and bubbling debts, which will pressure the growth. The USA and China might agree upon steps that would support each other in order to enhance growth and define a route aimed at strengthening the Yuan. Zoellick, moreover, suggested that prominent economies, especially the G-7, need to abandon monetary interventions. G-20 can come up with various norms to guide the instrument that developing countries need in order to cope with short-term hot money flows. Zoellick also talked about the obligation for G-20 countries to support growth by focusing on supply-side bottlenecks in developing countries. Finally, in compliance with the common consensus on the dollar reserve system, he suggested that G-20 should finalize this program with a plan to construct a common currency that is reflecting the emerging economic conditions. This new system will most probably comprise dollar, euro, yen, pound and Yuan and an open capital account.

In order to fight with global imbalances, which we see as the core reason for all the disasters faced in the world economy today, balancing of current accounts is recommended as a direct solution. The current account balance as a percent of GDP is a sign of international competitiveness for a country. Since surplus countries depends heavily on exports revenues with high saving ratings but weak domestic demand, they 
could increase service productivity and strengthen domestic consumption so that their imports increase. As it can be seen directly from Figure 2.3, these countries can be listed as Saudi Arabia, Germany, Russia, China, South Korea, Japan and Indonesia inside G-20. Deficit countries, on the other hand, depend heavily on imports, have a low saving rates and high personal consumption (\% of disposable income), could encourage exports and reduce domestic consumption (Velde, 2010). Furthermore, international reserves holds by surplus economies have an important role in stimulating global growth and development finance to developing economies. From figure 2.4, it can be depicted that China, Japan, Saudi Arabia, United States and Russian Federation are the first five countries holding the largest reserves inside G-20. Asian countries are holding reserves against the impacts of another economic crisis as insurance. This causes global imbalances again, so this position should be reversed and reserves should be used for development. This is possible by using the reserves as global investments (Velde, 2010).

\section{Figure1: Total Reserves of G-20 Countries as of 2011 (including gold)}

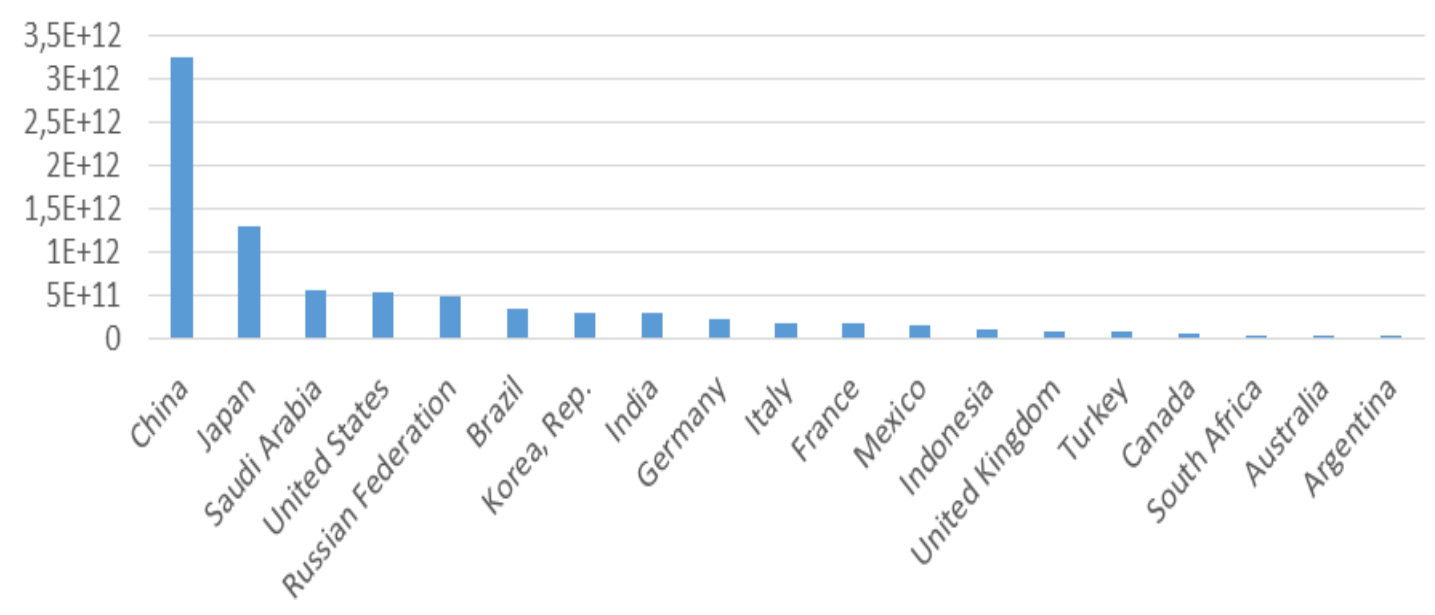

Source: World Development Indicators

Table 1: Total Reserves minus Gold Ranking of G-20 Countries (2011)

\begin{tabular}{lll}
\hline Ranking & Country Name & Total Reserves \\
\hline 1 & China & $3,20279 \mathrm{E}+12$ \\
2 & Japan & $1,25817 \mathrm{E}+12$ \\
3 & Saudi Arabia & $5,40677 \mathrm{E}+11$ \\
4 & Russian Federation & $4,53948 \mathrm{E}+11$ \\
5 & Brazil & $3,50356 \mathrm{E}+11$ \\
6 & Korea, Rep. & $3,04255 \mathrm{E}+11$ \\
7 & India & $2,71285 \mathrm{E}+11$ \\
8 & Mexico & $1,43991 \mathrm{E}+11$ \\
9 & United States & $1,36912 \mathrm{E}+11$ \\
10 & Indonesia & $1,06539 \mathrm{E}+11$ \\
11 & United Kingdom & 79272313250 \\
12 & Turkey & 78322384557 \\
13 & Germany & 66928149354 \\
14 & Canada & 65652141599 \\
15 & Italy & 49185199802 \\
16 & France & 48611516661 \\
17 & Argentina & 43226839533 \\
18 & Australia & 42783369933 \\
19 & South Africa & 42595178722 \\
\hline Source: World Development Indicators; http://data.worldbank.org/indicator/FI.RES.XGLD.CD).
\end{tabular}


International reserves can also be used to establish Sovereign Wealth Funds (SWFs). SWFs can be hold by the countries which has current account surpluses. That's why Asia is the top region in SWF investment, not surprisingly. EU and US are following the Asia (Velde, 2010). Again it is not surprising that the ratio of reserves to GDP is relatively high in many countries with SWFs. However, reserves are relatively lower in some countries, such as the countries in the Gulf area like Saudi Arabia, Kuwait, Oman, and United Arab Emirates, with SWFs of longer duration (Aizenman, Glick and NBER, 2008). According to Velde (2010), new and existing vehicles for SWFs may help channel global finance from surplus countries to the countries where returns on investment are utmost, or it could be directed to areas where increased liquidity is needed the most for systematic reasons.

\section{Analysis of Turkey's Gold Reserve Position in the G-20}

International reserve holdings and gold reserve holdings data are selected from the World Bank's indicator list. Both data are in current US dollars and calculated for the year of 2011. Due to the availability, the gold holding levels are calculated with the difference between the data of "total reserves minus gold" and "total reserves including gold". It is indicated by the World Bank that "total reserves excluding gold" comprise special drawing rights, reserves of IMF members held by the IMF, and holdings of foreign exchange under the control of monetary authorities.

\section{Figure 2: Total Reserves Excluding Gold Position of G-20 Countries (2011, current US\$)}

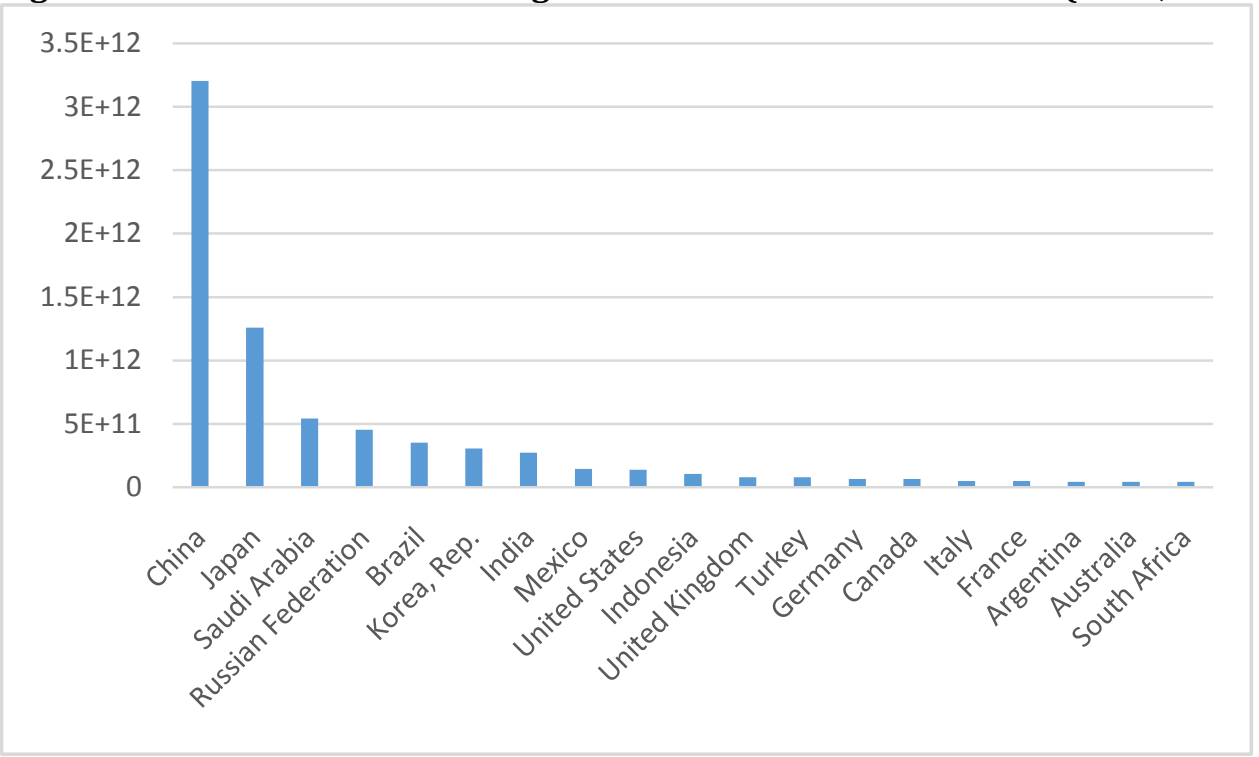

Source: World Development Indicators

According to the Figure4, two Asian countries, China and Japan are in the first and second place in total reserve level among G-20 countries while Saudi Arabia, Russia and Brazil are following them. Turkey is seen in the 12th place after United Kingdom. South Afrcia is seen as the country holding the least reserves but the last five countries (Italy, France, Argentina, Australia and South Africa) present similar results in terms of reserve numbers among G-20 countries. Figure 2 is consistent with the fact of international reserve hoarding of especially some Asian economies (specifically China) after the Asian financial crisis. It was a given fact that some economies such as China, Japan, Korea, Malaysia and Taiwan, have started to accumulate reserves at an increasing rate. After the event of Asian crisis, the ratios of reserve holding increases have been seen as 262\%,133\%,107\%, 124\% and 126\% respectively by the aforenamed countries (Cheung and Ito, 2009). Holding more of international reserves is generally considered as a positive indicator since it is thought as a tool to decrease vulnerabilities. It is easy to understand the reserve stocks in an economy with external surpluses. The country may be able to put aside some of its money since it earns more than it consumes (Akat, 2013). This is the case that can be easily seen in economies like China, Saudi Arabia, Russia, etc.

The case of G-20 leadership may be very beneficial if they can construct a system which rich and poor countries can push each other to utilize constructive policies and not just hold meetings inside themselves but instead try to reach the other through media (Bergsten, 2004). If they can manage to construct this kind of steering committee with key players such as China, Korea, Argentina or Brazil, it 
would be very crucial for global stability. After this point, G-7 would be weak for the stability job since the key players will be outside the group. Even the creation of G-20 in 1999 was an indicator that shows us the inefficient efforts of G-7 in dealing with the main problems of world economy (Bergsten, 2004). Hegemonic powers shift from one hegemony to another; during the financial crisis of 2008 which US hegemony apparently had been crushed, whereas China was mostly safe. Before one year ago the global crisis, Cox (2007) rightly asked 'Is the United States in decline - again?' Hence, based on current trends it seems to be only a matter of time until US hegemony ends and G.20 will rule the world.

Despite the fact that Turkey accounts for $1.1 \%$ of the global GDP, it ranks third, after Argentina and China, among G-20 countries in terms of growth with a growth rate of $8.5 \%$, based on the data of the third quarter of 2011. Turkey ranks $11^{\text {th }}$ in terms of population and $13^{\text {th }}$ in terms of per capita income. Turkey will have the term presidency of G-20 in 2015, following Mexico (2012), Russia (2013) and Australia (2014). In the G-20 Foreign Ministers Summit, held in February 2012 in Los Cabos. Moreover, other important issues were also addressed such as problems in the Middle East, economic crises, environmental problems and poverty. By touching upon the support that Turkey has been providing to the Least Developed Countries and stating that Turkey has promised to provide aid to these countries amounting to 200 million USD every year as part of the Istanbul Action Plan; he suggested that a common mechanism should be formed with the aim of bringing together G-20 countries and the Least Developed Countries. Turkey, which is the $16^{\text {th }}$ largest economy of the world and the $6^{\text {th }}$ largest one in Europe, sees G-20, which brings developed and developing countries together, as the most appropriate platform in addressing international financial and economic problems and attaining the coordination of global attempts to solve the economic crisis.

\section{Conclusion}

To conclude, it is undeniable that the sovereign debt crisis of 2008 has caused to shift global power from G7 countries to G 20 countries and forced the country to make concessions and adjust to new circumstances. Accordingly a tendency in gold reserves to grow; not only globally but also at the scale of individual countries is observed. Although Turkey is among these countries, its foreign exchange reserves are still very much above its gold reserves. In conclusion, whether as a part of a new exchange system or not, the rise in countries' confidence in gold is quite visible. This can be easily inferred from the amounts of reserves they hold in gold. In this respect, while some think that a return to the gold exchange system would be possible, some others believe that such a change could never be the case. As it is discussed so far, there exists a global consensus on the existence of problems regarding the dollar reserve system and quests are ongoing for a new global reserve money system to replace the USD. Last but not least, such gravitation towards gold and significant rises in gold prices render gold as the biggest candidate that a newly introduced system to be considered. Turkey continues to contribute to global governance reforms by actively participating in the works of G-20 at every level.

Recommendations: It is still being observed that the effects of the global financial crisis are clearly felt and people try to take measures, come up with new ideas and present much more marginal reform proposals accordingly. Although hearing such reform attempts from someone in a prominent position in the global economy spurs multifarious reactions, it nevertheless propelled everyone to think and discuss for attaining the best. If a change happens through a multi polar financial system, not a single currency will shine alone very strongly in the crisis times. Since they are just using dollars for all of their activities ranging from workers' payments to product sales, it will be more complicated for them to change among currencies. For example; they don't have to suffer from the cost of changing foreign-currency earnings into dollars. American companies will face with some problems such as exchange rate risks. On the contrary, total opposite will be true for the other nation's companies since they will be able to do business with their own currencies. Also the rivalry of Euro and renminbi is a very big change for the dollar. The other fact about US dollar is, the danger it faces about losing its safe haven status because of its federal debt (75\% of US GDP). Even if the dollar's reserve money status is not lost, it might be shared with other currencies. It is actually hard to replace a currency which has such credibility in international trade and investment. This situation creates a gap in international issues. Finally, today is not a day of just one currencies' hegemony. Before, technology was not developed as today and it was difficult to compare prices in different currencies. That's why it was not the case of using multi-currency by traders and bond issuers in order not to confuse their customers. Today, the situation is very different and it is possible to have more than one currency in the system. 


\section{References}

Aizenman, J., Glick, R. \& National Bureau of Economic Research. (2008). Sovereign Wealth Funds: Stylized Facts about Their Determinants and Governance. Cambridge, Mass.: National Bureau of Economic Research.

Aizenman, J. \& National Bureau of Economic Research. (2007). Large hoarding of international reserves and the emerging global economic architecture. Cambridge, Mass.: National Bureau of Economic Research. Akat, Asaf Savaş. (2013). Döviz Rezervi ve Kısa Vadeli Borç, Vatan. Retrieved from 22.01.2013 from http://haber.gazetevatan.com/doviz-rezervi-ve-kisa-vadeliborc/507905/4/yazarlar.

Bergsten, C. F. (2004). The G-20 and the World Economy. World Economics, 5(3), 27-36

Cheung, Y. W. \& Ito, H. (2009). A Cross-Country Empirical Analysis of International Reserves CESifo Working Paper Series (pp. 47).

Cox, J. (2013). Is the Dollar Dying? Why US Currency Is in Danger. Retrieved 10.05.2013, from http://www.cnbc.com/id/100461159.

Cox, M. (2007). Is the United States in decline-again? International Affairs, 83(4), 643-653

Delfeld, C. (2012). Will the Dollar Be Replaced As a Reserve Currency? Retrieved 10.05.2013, from http://www.investmentu.com/2012/May/dollar-reserve-currency.html

Eichengreen, B. (2011). The Dollar: Dominant no more? Retrieved 06.05.2013, from http://www.voxeu.org/article/dollar-dominant-no-more.

Eichengreen, B. (2011). Why the Dollar's Reign Is Near an End, The Wall Street Journal. Retrieved from http://online.wsj.com/article/SB10001424052748703313304576132170181013248.html

Eichengreen, B. \& Gupta, P. (2011). The Service Sector as India's Road to Economic Growth, NBER Working Papers 16757, National Bureau of Economic Research, Inc.

Prasad, E. S. (2014). The Dollar Trap, Princeton University Press, p. xiPosen, Adam S. (2008). Why the Euro will not Rival the Dollar. International Finance, 11(1), 75-100.

Stiglitz, J. (2009). Reform is Needed. Reform is In The Air. We Can't Afford to Fail, The Guardian. Retrieved from http://www.guardian.co.uk/commentisfree/2009/mar/27/global-recession-reform.

Stiglitz, J. (2010). One of the Main Lessons from the Financial Crisis is that the State Must Play a Key Role in Sustaining Economic Development. Retrieved 08/2012, from http://www.afdb.org/en/newsand-events/article/joseph-stiglitz-one-of-the-main-lessons-from-the-financial-crisis-is-that-thestate-must-play-a-key-role-in-sustaining-economic-development-5524/.

Tremblay, R. (2009). US Dollar to Remain Dominant International Reserve Currency for Many Years. Retrieved 10.05.2013, from http://www.marketoracle.co.uk/Article12484.html

Velde, D. W. (2010). G-20 Rebalancing, International Reserves and Development Finance the G-20 Framework for Strong, Sustainable and Balanced Growth (pp. 25-27). London UK: Overseas Development Institute. 